\title{
Comparative analysis of stylistic devices in the English and French songs of independent scene
}

\author{
M. Sterlikova \\ Yuri Fedkovych National University of Chernivtsi, Department of English \\ Paper received 10.01.19; Accepted for publication 19.01.19.
}

\begin{abstract}
https://doi.org/10.31174/SEND-Ph2019-189VII55-13
\end{abstract}
\begin{abstract}
The article presents a contrastive analysis of the stylistic features of the English and French songs of the "independent scene". Poetic language differs from prose by the division on verses. The disadvantage is that it is not clearly defined what the poetic originality of line compared to any other is. The material of the research is independent music (often shortened to indie music or indie) is music produced independently from major commercial record labels or their subsidiaries, a process that may include an autonomous, do-it-yourself approach to recording and publishing. It's relevant to study this topic because of the direction of the modern linguistic research on comprehensive study of different types of texts, their structural characteristics, implementing them into a number of lingual means and pragmatic function. The study aims to identify stylistic features of English lyrics of the independent scene by analyzing their linguistic-stylistic features.
\end{abstract}

Keywords: lyrics, genre, stylistic devices, expressive means, comparative analysis, comparative stylistics.

In this article, in general terms, the problem of analyzing the process of studying a song is set, which, as is well known, is one of the oldest forms of a human creative work. The relevance of the study of the song lyrics is explained by the importance of this type of texts for the society and the ability to use expressive means typical for a song and to optimize communication in other situations. It comes as no surprise that a lot of works of linguists are devoted to the study of different types of songs. Significant interest in the lyrics of modern songs is evident in a number of works of the recent decades. But in general, the long history of studying song texts remains unexplored. The purpose of this article is the result of comparing the stylistic devices of the English and French lyrics.

Nowadays English plays a huge role in the lives of many people. Millions of people from different countries speak English, use it either at home or at work. As for international relations, the English language can be compared only with French. Learning English and French and the culture of their speakers is also possible through the lyrics. Songs are of great importance in the life of a person, especially young one, who is the main consumer of music. Young people sometimes just listen to it from day to day, without thinking about the particular lyrics, their specifics, culture, mood, etc. We often understand individual words or expressions incorrectly and distort the meaning of the whole text. If we delve deeper into the content of a song, we can find in it a hidden meaning transmitted through various stylistic devices, the rarest meanings of words, whereby the listener, mainly the young, is influenced. Therefore, the study of the linguistic and specific features of English and French lyrics and the linguistic means of their influence on people is relevant.

What was first - text or music? It is generally known: "Firstly there was the Word", because to give a word, a name means to attach to the world, to create a new form of existence. The first word that gave rise to everything was intonationally expressive, capable of the power of its energy to awaken the will to creation. Considering the role played by verbal art in the society, literature is often placed at the heart of this aesthetic structure. Because at first there actually was the Word, in the "clothes" of which the fire of all other arts was lit [7, p. 21].
F. Nietzsche, referring music to the sphere that stands "above any phenomenon," noted that in the dichotomy (consecutive division of the whole into two parts) of "music is the word" the leading element is music, since it embodies everything that a word can contain. Music releases the word from superfluous concretization and discovers the hidden meaning in it [4, p. 472-473]. The philosopher believed that the leading beginning in the song, which sets the tone for the whole work of art, is music. However, with its own means, without the help of words, music can't express all thoughts. Music is not specific to the thoughts, messages that contain information of facts. In practice one of the art forms often becomes dominant, because its own specifics subordinate others.

The subordination is gaining a variety of options - from hidden assimilation to its intense demonstration [7, p. 20]. However, musicians have known the difference between music since olden times in which the word dominates and the music that dominates the word. The interaction of words and music in a song depends on the musical or literary genre. On the one hand, there are tendencies to dissolve the word in music (for example, when the listener perceives the performance of the vocal work in the original language that he doesn't understand at all). Musical understanding replaces the understanding of language. On the other hand, there were always attempts to bring music to the language. In most of the literary and musicological studies, the question of the "supremacy" of a component in the song text is resolved in favor of melodious. "In a song, text and music are represented as if they are equivalent, but in reality the musical image conquers itself and absorbs the verbal and poetic image. Yes, music triumphs over poetry." [2, p.49]

Lyrics as a kind of belles-lettres style are of considerable interest for modern linguistic researchers. Such scientists as N.D. Goliasheva, M.V. Divina, P.R. Yarmullina, Y.E. Plotnitsky, O.S. Kostryukova and many others, studied the features of English songs, examined their linguocultural characteristics, analyzed their nature, creation, essence. R.R. Yarmullina, analyzing the songs of contemporary performers, came to the conclusion that in popular songs that lexical repetitions, metaphors, hyperbolas are mostly encountered. 
This article is based on the material of the songs of the British and French bands of the independent scene, playing mostly obscure and melancholic genres called post-punk and coldwave.

Contrastive analysis of the stylistic features includes the texts of the British band Joy Division, which is a vivid representative of the post-punk genre, working from 1976 to 1980, until their vocalist and author Ian Curtis committed a suicide. For the analysis there were taken two albums of the band 'Unknown Pleasures' (1979) and 'Closer' (1980), which had a great influence on the followers of this genre. As to their lyrics, imagery and words revolving around "coldness, pressure, darkness, crisis, failure, collapse, loss of control" recur in his songs. [6, p. 110.] In 1979, NME journalist Paul Rambali wrote, "The themes of Joy Division's music are sorrowful, painful and sometimes deeply sad. [5, p.10]. Music journalist Jon Savage wrote that "Curtis's great lyrical achievement was to capture the underlying reality of a society in turmoil, and to make it both universal and personal," while noting that "the lyrics reflected, in mood and approach, his interest in romantic and science-fiction literature" [8].

As regards the French lyrics, the texts of the genres post-punk and coldwave of some bright representatives were chosen for analysis. The French "independent scene" is not sufficiently popular and mainstream, so a research of this genre is of particular interest for modern linguists. It is impossible to single out one particular performer of French "independent scene", so the analysis will be presented on the material of the lyrics of such bands as Guerre Froide, Opéra de Nuit, Opéra Multi Steel, Asylum Party and La Femme. All the bands in the list, with the exception of the last one, worked around in the same period as Joy Division did. The bands taken for analysis are representatives not only of the post-punk genre, but also of coldwave, that is a French variant of post-punk music, primarily spread in France. The lyrics are even darker and gloomer than in Britain, where main topics are depression, despair, pain, death, sorrow, etc.

Let's consider such phonetic stylistic devices like alliteration and rhyme. The essence of alliteration lies in repetition of similar sounds, in particular consonant sounds. It doesn't bear any lexical meaning unless we agree that a sound meaning exists as such. The examples of alliteration in French lyrics are:

I. Ami? amant?

Amour cassant

La mort est elle aussi belle (Opéra de nuit - Ami! Amant!)

II. Mais où va le $\underline{\text { monde ? }}$

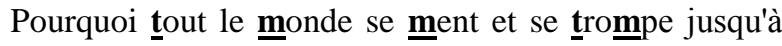
se traîner dans la misère la plus tótale ?

Donner $\underline{\mathbf{m}}$ a confiance et $\underline{\mathbf{m}} \boldsymbol{}$. cœur

Pourquoi ça me fait si peur ? (La femme - Où va le monde)

As we see from the examples I, II, the authors create alliteration of the sound [m] to create a somnolent sound and to cause the association with love - amour (French). The sound [t] combines with the [m] and they show that this song is rather melancholic than aggressive.

III. Le souririre de l'ombre

M'attirait dans le vide de son univers.
J'allais me fondre

Dans ses bras si fragiles et lui donner ma chair. (Opéra de nuit - Le sourire de l'ombre)

In these extracts we see the sound $[\mathrm{R}]$ is frequently used to give the intent effect.

The examples of alliteration were also found in the English lyrics: long

I.Gotta find some therapy, this treatment takes too

Deep in the heart of where sympathy held sway

Gotta find my destiny, before it gets too late. (Joy Division - 24 hours)

The sound [t] in English has the same effect as it was given above in the French one.

II. A burden to keep, though their inner communion

Accept like a curse an unlucky deal. (Joy Division The eternal)

The sound [k] produces a harsh, sharp atmosphere compared to [t] as it is given in the example I.

III.But we remember

$\underline{\text { When }}$ we were young

And all God's angels beware

And all you judges beware. (Joy Division - Insight)

The alliteration of words with [w] sounds like waves and creates a mesmerizing effect.

According to Galperin I.R., he singles out full rhymes (identity of the vowel sound and the following consonant sounds in a stressed syllable, e.g.: might-right), incomplete rhymes that can be divided into vowel rhymes (the vowels of the syllables in corresponding words are identical, e.g.: flesh-fresh, press) and consonant rhymes (concordance in consonants and disparity in vowels, e.g.: worth- forth, flung-long). There are also eye-rhyme, where the letters and not the sounds are identical, e.g.: love- prove, have-grave. The last example of rhyme is called internal. The rhyming words are placed not at the ends of the lines but within the line, as in: I bring fresh showers for the thirsting flowers. Here were found different kinds of rhyme either in French or in English lyrics.

Let's consider examples selected from the French lyrics:

Full rhyme: 1'amant-semblant, amant- cassant, ellebelle (Ami amant), l'ombre-fondre, sauvage-image (La sourire de l'ombre)

Incomplete rhyme: infinie-sorties, visage-cage, sourire-sortir (vowel) (asylum party - la nuit), fort-encore, pur-obscur (vowel), final-fatal (consonant) (ami amant), en croix-désespoir (vowel) (Annabella), mal-normal (La femme - ou va le monde?), néant-enfant, insolites'effrite, étoiles-voile (vowel) (La sourire de l'ombre)

Eye-rhyme :se mentent- se trompent (La femme - ou va le monde?)

The examples of rhymes of the English lyrics are:

Full rhyme: twist-exist (Joy Division - Atrocity exhibition) removed-improved, side-died (A means to an end), pride-side, go-know, call-all (24 hours), all-wall (Day of the Lords), waste-taste, all-fall (Insight), dust-rust, rowshow (Interzone), night-sight, tough-enough, know-show (Transmission)

Incomplete rhyme: wide-inside, prize-life (Joy Division - Atrocity exhibition), love-above, can-am (Isolation), behind-kind, highs-sky, needs-eat (vowel) soil-call (consonant) (A means to an end), time-find, reach-keep, 
find-desire (vowel) (24 hours), heat-weak, pain-obtained, road-closed (vowel) (Day of the Lords), marked-heart (vowel) (Candidate), end-descend, door-anymore, beware-care-there (Insight), see-free (New dawn fades), round-get out (Interzone)

Eye-rhyme : move-love (24 hours)

Having provided this analysis, we see that there are more different types of rhymes in English than in French lyrics; the prevailing number of rhymes in both languages is evidently an incomplete vowel rhyme. It's rather difficult to find the eye-rhyme, because the perception is mostly focused on reading the words with the correct pronunciation, but in the examples above we see that authors try to use this kind of rhyme. An internal rhyme wasn't found in the taken lyrics.

The analysis of Syntactical stylistic devices shows, it's possible to pick out examples of asyndeton and polysyndeton. The stylistic device of connecting sentences polysyndeton - is well-defined in the lyrics of the British band Joy Division, rather than in French. In the song 'She's lost control' almost each line starts with the conjunction and. As for asyndeton - that is the opposite to polysyndeton - is also more inherent in the English lyrics. We can see the examples below of each stylistic device in both languages:

Polysyndeton in the French lyrics is found in the following lines:

I.Et toujours ce goût pour le néant

Ou plutôt pour le moment qui le précède

Ou plutôt pour le moment qui le précède

Et toujours ce goût pour le néant. (Guerre froide - Ersatz)

In English lyrics the examples are:

II.Forgive and forget's what they teach

Or pass through the deserts and wastelands once more

And watch as they drop by the beach. (JD-Passover)

III.And she's clinging to the nearest passer by

She's lost control

And she gave away the secrets of her past

And said I've lost control again

And a voice that told her when and where to act

She said I've lost control again

And she turned around and took me by the hand and said

I've lost control again

And how I'll never know just why or understand

She said I've lost control again

And she screamed out kicking on her side and said

I've lost control again

And seized up on the floor, I thought she'd die

She said I've lost control. (JD - She's lost control)

IV. And we would go on as though nothing was wrong

And hide from these days we remained all alone. (JD -

Transmission)

V. I'll take no pity from you friends

Who is right, who can tell

And who gives a damn right now. (JD - Disorder)

Asyndeton is traced in the French lyrics:

VI.Je suis l'ami

Tu vois l'amant

Tu me caresses

Tu fais semblant (Opéra de nuit - Ami! Amant!)

English examples are:
VII.A change of speed, a change of style

A change of scene, with no regrets

A chance to watch, admire the distance.

Oh, I've walked on water, run through fire

Can't seem to feel it anymore. (JD - New dawn fades)

VIII. Staying in the same place, just staying out the time

Touching from a distance, further all the time. (JD Transmission)

IX.Mother I tried please believe me,

I'm doing the best that I can,

I'm ashamed of the things I've been put through,

I'm ashamed of the person I am. (JD - Isolation)

$\mathrm{X}$. This is a crisis I knew had to come

Destroying the balance I'd kept

Doubting, unsettling and turning around

Wondering what will come next. (JD - Passover)

XI. We knocked on the doors of Hell's darker chamber

Pushed to the limit, we dragged ourselves in

Watched from the wings as the scenes were replaying

We saw ourselves now as we never had seen. (JD Decades)

From the examples illustrated above, we can make a conclusion that either polysyndeton or asyndeton are more often met in the English lyrics, however these syntactical stylistic devices are also traced in the French lyrics to a lesser degree.

Rhetorical question in both types of lyrics is a question which is no longer a question but a statement expressed in the form of an interrogative sentence. There are some examples found in the analyzed material:

- French lyrics -

I.Mais où va le monde?

Où sont mes vrais amis ?

Pourquoi je me méfie?

Qu'a t'on put bien faire de tous ces sacrifices?

Quel animal va-t-il en sortir?

Pourquoi ça me fait si peur?(La femme - Où va le monde)

II.Pourquoi cette grimace sur ton visage?

Pourquoi tout le monde se ment et se trompe jusqu'à se traîner dans la misère la plus totale ? (Asylum party - La nuit)

- English lyrics -

III.Is this the role that you wanted to live?

Can I go on with this train of events?

Is this the gift that I wanted to give? (Passover)

IV.Here are the young men, the weight on their shoulders

Here are the young men, well where have they been?

Where have they been?

Where have they been?

Where have they been?

Where have they been? (Decades)

In the selected for the analysis material only two examples of rhetorical question in every type of lyrics were found. The first song Où va le monde also contains the repetition of the rhetorical questions as well as the second song in English. The rhetorical questions re-enforces the essential quality of interrogative sentences and uses it to convey a stronger shade of emotive meaning.

Let's consider the syntactical stylistic device that is inherent mostly in lyrics. Repetition is an inalienable part of 
songs. Because of it we can perceive the lyrics and the song itself much better. Repetition is the simple repeating of a word, within a sentence or a poetical line, with no particular placement of the words, in order to secure emphasis. Epizeuxis, anaphora and epiphora are mostly found in English and French lyrics.

In the English lyrics there were found all the kinds of repetition:

I. God in his wisdom took you by the hand

God in his wisdom made you understand

God in his wisdom took you by the hand

God in his wisdom made you understand (JD - Colony)

The outro of the song contains anaphora God in his wisdom and the parallel repetition abab.

II. The song 'A means to an end' has no chorus, but there are two different hooks that can be treated as chorus because of their repetition:

[Hook 1]

I always looked to you

I always looked to you

I always looked to you (After verse 1).

[Hook 2]

I put my trust in you

I put my trust in you

I put my trust in you (After verse 2).

III.The song Insight contains the bright example of epiphora:

Tears of sadness for you

More upheaval for you

Reflects a moment in time

A special moment in time

Yeah we wasted our time

We didn't really have time.

IV. Epizeuxis that is found in the song 'Transmission' urges listeners to dance to the radio and follow the accurate rhythm:

Dance, dance, dance, dance, dance, to the radio

Dance, dance, dance, dance, dance, to the radio

Dance, dance, dance, dance, dance, to the radio

Dance, dance, dance, dance, dance, to the radio.

French lyrics also contain the examples of repetition:

I.The song 'Demain Berlin' by Guerre Froide contains the repetition of lines in the old version of this song. The newest one is bilingual: the same line is firstly in French and then is repeated in English.

Tandis que tu t'habillais tout en noir

Que tu t'habillais tout en noir./

You were as cold as an iceberg

Aussi froide qu'un iceberg. - Here we also see the example of bilingual repetition.

II. Anaphora of the word maintenant is found in the song La nuit by Asylum party:

Maintenant tu vois dans la nuit

Maintenant tes griffes sont sorties.

III. The song Annabella by Opéra de nuit has epizeuxis that is conveyed by the girl's name to express the grief of Annabella's decease:

Annabella / Annabella. - It's repeated for 10 times during the song.

In this analysis we see that most of the songs count the repetition, epizeuxis, anaphora and epiphora. This stylistic device is definitely peculiar to lyrics. Nevertheless there is no epiphora in the French lyrics, all other types are widely spread either in English or in French.

Let's consider Lexical Stylistic devices. The most popular are epithet and metaphor.

The first lexical stylistic device that will be examined is epithet. For instance, in the lyrics of the album 'Closer' by Joy Division we found 10 epithets that are given below:

painstaking devotion; a wayward distraction; lucky prize; feverish smiles; broken homes; a cruel wind; eternal rights; stranger waves; pitiful eye; mercenary hand; love-shattered pride.

In contrast to English, French lyrics contain 13 cases of using epithet:

de mon visage diaphane; une bouche filigrane; mon regard foudroyé; des histoires futiles; son corps fragile; ses bras si fragiles; les mots mortels; délice irréel; la faim infinie; notre amour aussi fort; les sentiments sont maquillés; des amours muettes dissimulées; un regard désabusé.

The epithet is a direct and straightforward way of showing the authors' attitude towards the things described in the lyrics. The evidence proves that there are more epithets in French than in English lyrics; however the number of analyzing songs was identical.

The next lexical stylistic devices that are analyzed are metaphor and metonymy. In the English lyrics based on Joy Division albums there were found 22 cases of metaphor that are illustrated below:

he kills for a prize; the sickness is drowned by cries for more; he calls her aloud from above; a blindness that touches perfection / but hurts just like anything else; a cry for help, a hint of anesthesia; we fought for good, stood side by side; our vision touched the sky; instincts that can still betray us; a journey that leads to the sun; an abyss that laughs at creation; weary inside, now our heart's lost forever; can't replace the fear, or the thrill of the chase; I've got the spirit, lose the feeling / Take the shock away; there's blood on your fingers brought on by fear; guess your dreams always end / They don't rise up, just descend/ Those with habits of waste / Their sense of style and good taste/ Tears of sadness for you; a loaded gun won't set you free; confusion in her eyes that says it all; but I could only stare in disbelief; the power and glory of sin; to synchronise love to the beat of the show.

And the French lyrics contain 14 examples of using this stylistic device:

je flirte avec la folie; le monde-image s'efface; le sourire de l'ombre; la certitude s'effrite; le sourire de l'ombre / M'attirait dans le vide de son univers; mon regard transperçait; seul mes yeux se rappellent / Cette histoire, délice irréel; le sourire de l'ombre dans la brume sans étoiles / S'effaçait lentement; pour mieux plonger dans le fleuve du temps; écoute les voix de la nuit; mon cri s'étire dans le silence; dans les catacombes de mon Désespoir; j'vais te rejoindre dans ton royaume; mes larmes et mon Sang coulent sur ton visage.

Metonymy was also found in the lyrics but it encounters rarely. In the French lyrics there was just one case of metonymy: hurler la faim infinite;

whereas English lyrics contain 5 examples: asylums with doors open wide; this is a crisis I knew had to come / Destroying the balance I'd kept; the sound from broken 
homes; To the centre of the city where all roads meet / Waiting for you; to the depths of the ocean where all hopes sank / Searching for you.

From the analysis it's possible to say that metaphor and metonymy were used to express the thought indirectly, to make the lyrics eloquent; sometimes these devices save the words allowing to express less but accurately. The lyrics are "decorated with" SD giving expressiveness to the text.

Among some other lexical stylistic devices we illustrate the examples of simile in the English and French lyrics:

cry like a child, though these years make me older; scattering flowers washed down by the rain / Stood by the gate at the foot of the garden / Watching them pass like clouds in the sky; a burden to keep, though their inner communion / Accept like a curse an unlucky deal; a blindness that touches perfection / But hurts just like anything else; the light shined like a neon show; ta voix qui m'appelle comme un chant éternel; je pars comme je suis venu, encore plus déçu.

We see that this stylistic device is more often met in English texts, nevertheless it's possible to encounter it in French lyrics. Similes develop conceptual thinking, give rise to associations and the lyrics are apprehended easier.

And we illustrate the example of oxymoron in the song 'Le sourire de l'ombre' by Opera de nuit that is used to just create the stylistic effect and is only found in French: ombre blanche.

Having carried out a stylistic analysis of the songs of the band "Joy Division", we came to the conclusion that
Ian Curtis often used various repetitions, anaphoras, epiphoras, etc. Along with the basic phonetic expressive means, including alliterations and various types of rhymes, these stylistic devices help to make the text more saturated, emotional, thrilling, rhythmic and easy to perceive. Among lexical stylistic devices there are metaphors, metonymies, epithets and similes emphasizing not anger and energy but mood and expression, pointing ahead to the rise of melancholy.

Concerning the French lyrics, it's possible to infer that these texts are also abundant in stylistic devices that were found in the English lyrics, nevertheless the French lyrics count bigger amount of epithets in contrast to English, there was encountered the case of oxymoron, but as for the other devices, they are found more seldom.

To conclude the analysis, we can say that the genres of post-punk and coldwave in the English and French languages are disclosed beforehand by the galore of metaphors, epithets, similes, different kinds of repetition that include anaphora, epiphora; rhetorical questions, alliteration of different consonants to create the tense and melancholic atmosphere and polysyndeton. It's much easier to encounter incomplete rhyme in every type of lyrics. All stylistic devices of different language levels are used in convergence and convey some hidden meaning. Therefore, in our opinion, English and French songs of these genres are well suited for studying culture (especially youth subculture), value orientations of the representatives of the country where one or another band was formed and among whom it is popular.

\section{REFERENCES}

1. Genius Media Group Inc. 2017 https://genius.com/artists/Joydivision

2. Kremlev Yu. A. O meste muzyki sredi iskusstv. M.: Muzyka, 1966. 64 s. 3. Langleben M. Melodiya v plenu u yazyka // Muzyka i nezvuchashchee: sbornik / otv. red.

3. NET VADOR 2004-2017 Paroles Musique - Tous droits réservés | Paroles-musique.com - www.paroles-musique.com

4. Nietzsche F. Rozhdenie tragedii iz dukha muzyki // Nietzsche F. Tak govoril Zaratustra. K genealogii morali. Rozhdenie tragedii. Volya k vlasti. Posmertnye aforizmy. Minsk: Kharvest, 2007.

5. Rambali, Paul (11 August 1979). "Take No Prisoners, Leave No Clues". NME.

6. Reynolds, Simon (2005). Rip It Up and Start Again: Postpunk 1978-1984. Penguin.

7. Rysak O. O. «Najpershe - muzyka u Slovi»: problemy syntezu mystectv v ukrai'ns'kij literaturi kincja HIH - pochatku HH stolit'. Luc'k: RVV «Vezha», 1999. 402 s, p. 21

8. Savage, Jon. "Controlled chaos". The Guardian. Retrieved 21 March 2016 